\title{
安心・晏全な電波利用環境の 整備について
}

総務省総合通信基盤局電波部電波環境課

\section{1}

電波の安全性に関わる制度

携帯電話の普及が進み，平成 25 年度末では携帯電話 の加入契約数は 1 億 4,401 万件に達し, 今なお携帯電 話の契約数は増加傾向にある. 更に今後, IoT (Internet of Things）や5G などの無線を活用した新たなサービ スの実現に向け，世界中で取組みか加速している。

一方，人間には見えない電波に対する安全性について の懸念あるいは関心は，これまでも少なからず存在して いる，電波がより身近な存在となる中，電波の人体や医 療機器等へ与える影響について, 電波の安全性を確保す るための諸制度が整備されている（図 1).

\section{1 電波防護指針}

電波の生体等への影響に対する不安や疑問に対応す るため, 総務省では, 健全な電波利用の推進を目的とし， 人体に影響を及ぼさない電波の強さの基準となる「電波 防護指針」を平成 2 年に電気通信技術審議会からの答 申として受けた ${ }^{(1)}$.

指針では，電波のエネルギー量と生体への作用との関 係を可能な限り定量的に明らかにし，電波が人体に影響 を及ぼさない安全な状況であるかどうかを判断する基本 的な考元方とそれに基づく基準值等を示している.

同指針に関しては，これまで，携带電話等について電 波のエネルギーが人体に吸収される場合の基準值「局所 吸収指針」の導入や，低周波領域についての基準值の改 訂など，最新の科学的知見の反映に務めている.

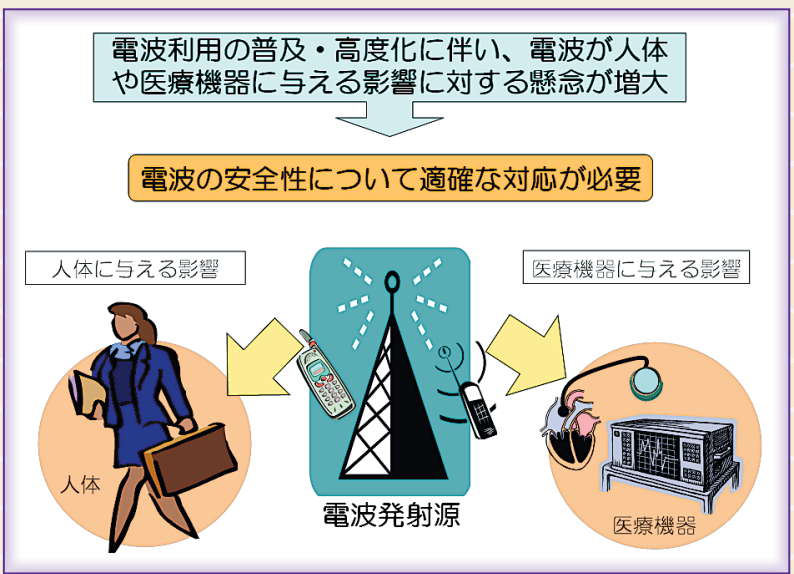

図 1 電波の安全性についての対応の必要性

\section{2 国際的な取組み体制}

電波の安全性については，WHO（世界保健機関）を 軸とした国際的機関による取組み体制（図 2）が構築さ れ，国際ガイドライン等が策定されている。

(1) WHO

WHO では，電波の人体への影響に関する各国の研究 成果を集め,リスク評価を行い,ファクトシートや環境保 健クライテリア(EHC : Environmental Health Criteria) として公表を行っている ${ }^{(2)}$.

また，WHO の下部組織として，様々な物質等の発が ん性の有無について調査・公表を行う IARC（国際がん 研究機関）は，無線周波電磁界について，発がん性に関 する限定的な証拠が存在するとして，「ヒトに対して発 がん性があるかもしれない」(グループ 2B）に分類*1 している。

これに関してWHO では，「携帯電話が潜在的な健康 リスクをもたらすかどうかを評価するために，これまで 20 年以上にわたって多数の研究が行われてきました。 今 日まで，携帯電話を原因とするいかなる健康影響も確立 されていません.」とし, 更なる検証が必要だとしている。

（2）ICNIRP（国際非電離放射線防護委員会）

中立的な非政府組織として, 平成 4 年, ICNIRP が設立 された。世界各国の電波の安全性に関わる専門家で構成 されており，電波に関する人体防護ガイドラインの勧告 と，関連する科学的な情報の提供を主な役割としている。

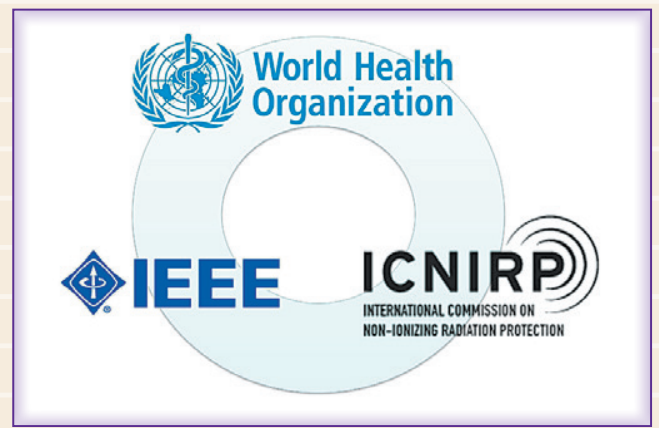

図 2 国際的な取組み体制

*1 IARCによる発がん性評価は, 発がん性があるかどうか, 「科学的証拠の強さ(確かさ)」を分類しているものであ り，どの程度リスクがあるか，「発がん性そのものの強 さ」を評価しているものではない. 
ICNIRP の国際ガイドラインは，日本をはじめ，世界 各国の規制において参照されている ${ }^{(3)}$.

(3) IEEE（電気電子学会）

ICNIRP と同様に, IEEE においても WHO や ICNIRP 等の国際機関と協力し, 電波の安全性に関する国際がイ ドラインの勧告等を行っている.

\section{3 電波法令における制度}

電波防護指針における基準值を基に，無線機器等に対 する規制が電波法令へ導入されている。

\section{（1）電波の強度に対する安全施設}

電波の強さが基準值を超える場所に一般の人々が容 易に出入りできないよう, 安全施設の設置を義務化.

\section{（2）人体に吸収されるエネルギー量の許容值}

人体に吸収される電力の比吸収率（SAR：Specific Absorption Rate) *2 (図 3) の許容值 $(2 \mathrm{~W} / \mathrm{kg}$ ) を人体 近傍で使用する携帯電話等の無線機器に対して強制規格 化している。平成 28 年 3 月頃から，3.5 GHz 帯を用い

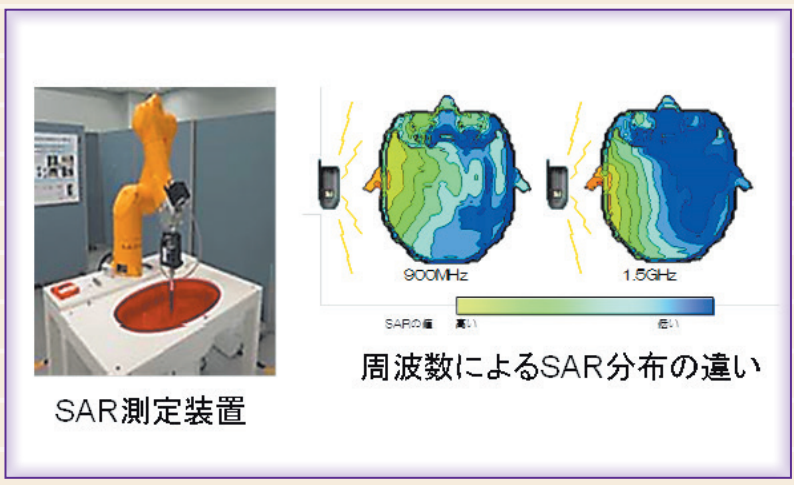

図 3 SAR 測定

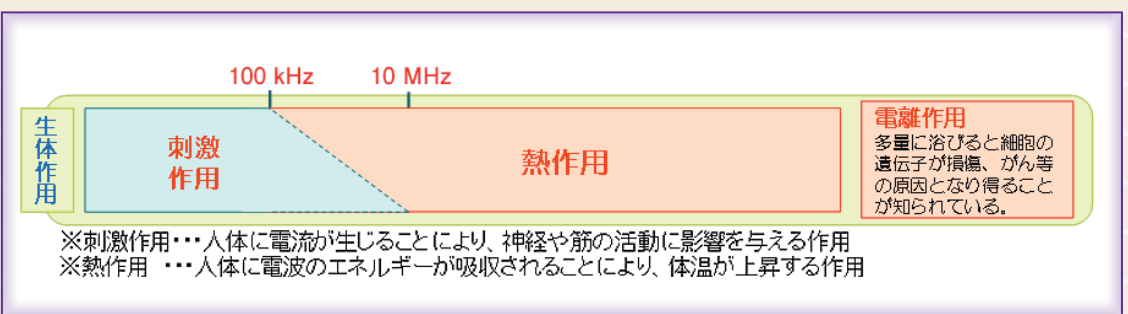

図 4 電波が生体に与える影響

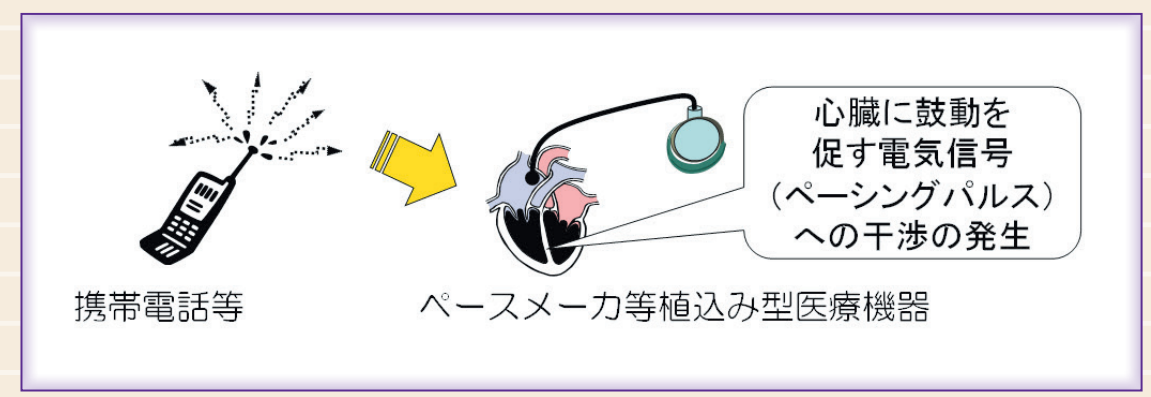

図 5 携帯電話等の電波による医用機器への影響

*2 生体が電磁界にさらされることによって単位質量の組 織に単位時間に吸収されるエネルギー量.
た携帯電話サービスが運用開始予定であり，人体頭部に おける SAR 測定の対象周波数の上限を, $3 \mathrm{GHz}$ から $6 \mathrm{GHz}$ へと拡張する改正省令が平成 27 年 12 月 1 日か ら施行された。

\section{2 電波が生物に及ぼす作用}

電波が生物に及ぼす影響（図 4）は，これまで長らく 世界各国で研究が進められてきた。現在の科学的知見で は，生物が強い電波を浴びると，周波数に応じて「刺激 作用」や「熱作用」が生じることが判明している。

(1) 刺激作用

刺激作用は $100 \mathrm{kHz}$ 以下の周波数領域で生じる現象 である，電波を受けて体内に生じる誘導電流が神経や筋 の活動に影響を与え，刺激作用に伴う不快感，中枢及び 末梢神経組織刺激等の生物学的反応が生じる.

（2）熱作用

熱作用は $10 \mathrm{MHz}$ 以上の周波数領域で生じる現象で ある。人体が電波にばく露された際，電力を吸収し，体 内深部温度が上昇する。ただし，人体の誘電率が均質で ない等のため，周波数や電波強度分布などにより，体内 での発熱分布が大きく異なる.

\section{3 医療分野における電波に対する関心の高まり}

近年，医療機関において無線機器を利用する機会が増 加したことなどから，医療分野における電波に対する関 心が高まっている。このため，総務省において医療分野 における電波の安全性の確保に向 けた取組みを推進している。

\section{（1）植込み型医療機器への影響}

携带電話等の電波が医用機器へ 与える影響（図 5）に関する懸念を 受け，平成 9 年，不要電波問題対 策協議会において，「医用電気機器 への電波の影響を防止するための 携帯電話端末等の使用に関する指 針」が策定された ${ }^{(4)}$. 同指針では, 医療機関の屋内では，診察室，手 術室や集中治療室等へは携帯電話 を持ち込まないことや，植込み型 心臓ペースメーカと携帯電話端末 等を $22 \mathrm{~cm}$ 程度以上離すことが推 奨された。

これを受け，医療機関では携帯 電話の利用を全面禁止とする措置 が広くとられていた。また，電車 
内の携帯電話利用のマナーとして「優先席の付近では 携带電話の電源を OFFに」というルールが全国で普及 した.

これに対して，医用機器等への影響が大きかった第 2

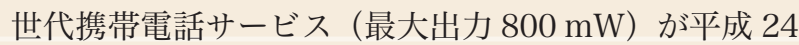
年 7 月をもって終了し，より影響が小さい第 3 世代携帯

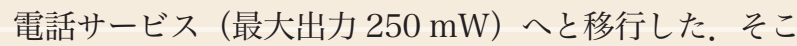
で総務省では，植込み型医療機器の電磁耐性 $(\mathrm{EMC})$ に 関する国際規格（ISO14117 等）や実機を用いた実験結 果等を踏まえ，平成 25 年 1 月に指針を改定し，携帯電 話と植込み型医療機器との推奨離隔距離を $15 \mathrm{~cm}$ 程度 以上へと緩和を図った。更に, 平成 27 年 8 月, ペースメー カや除細動器以外の植込み型医療機器等を対象として調 查を行った結果を反映した指針の改訂が行われた ${ }^{(5)}$.

このような指針の変更や，社会状況の変化に対応し， 電車内の優先席付近等における携帯電話使用マナーを 「混雑時には携帯電話の電源を $\mathrm{OFF}$ とする動きが広ま りつつある(図 6 , 表 1 )。

（2）医療機関における携带電話利用の推進

医療機関では携帯電話利用が避けられていたが，その 後の指針や技術動向等の変化, マナー等を勘案し, 独自に 携带電話利用ルールを定める医療機関が増加している.

このような状況に対して，平成 26 年に「医療機関に おける携帯電話等の使用に関する作業部会」が電波環 境協議会に設置された。安全を確保しつつ携带電話の 利用を推進するための方策について議論がなされ，「医 療機関における携帯電話等の使用に関する指針等」(図 7）が平成 26 年 8 月に公表された ${ }^{(6)}$. 医療機関におけ る携帯電話等の積極的活用は，医療の高度化・効率化 や患者の生活の質（QOL：Quality of Life）の向上に 大きな効果が見込まれることからも，厚生労働省を通 じて本指針等を各医療機関へ周知するなどの取組みを 進めている.

（3）医療機関における電波利用の推進

また，平成 27 年 9 月，高市総務大臣からの 指示を受け，医療機関における電波環境の改善 方策等について検討を行う「医療機関における 電波利用推進部会」が電波環境協議会に設置さ れた（図 8)。医療機関において無線機器を利 活用する機会が増え，無線に関わる問題が生じ ていることから, 現状の把握や改善方策や電波 の管理方策等に関する検討が進められている.

医用テレメータを例にとれば，LED ランプ から放射される電磁波が雑音として混入し，テ レメータが利用できなくなるトラブルの顕在化 などが明らかになった，また，携帯電話に関し ては，平成 26 年度の指針を受けてその利用を
拡大する動きが現れつつも，具体的な実現方策や利用 ルールなぞを模索している機関もあり，その支援の必要 性について着目されている。

医療の高度化の観点からも，医療機関における電波の 利用推進は不可欠であり，その適切な利用環境の整備は 重要であるが，これまで手つかずであったことから，急

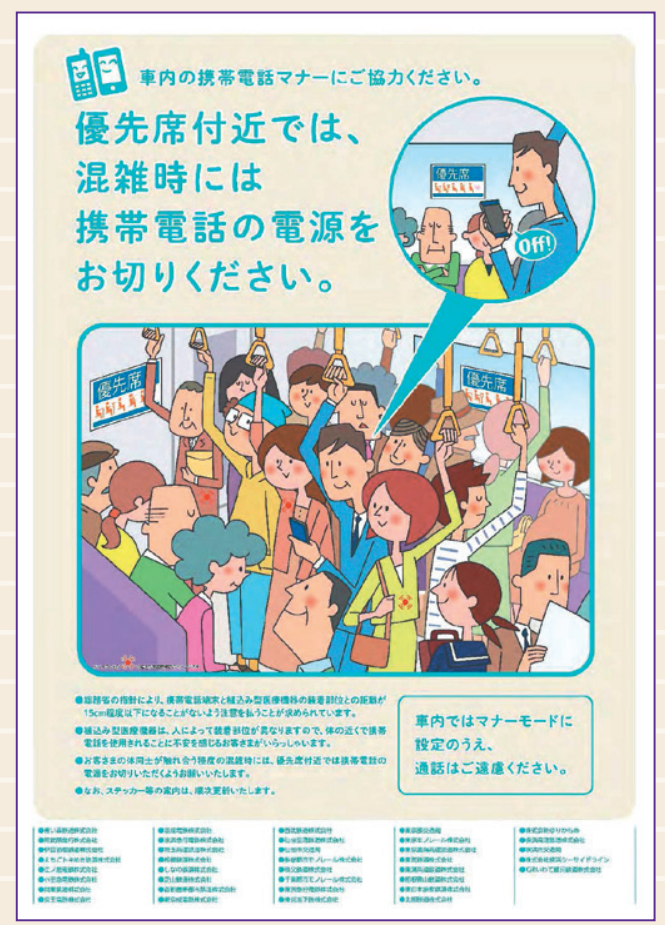

図 6 電車内優先席付近の新たなマナー啓発ポスター (関東・東北・甲信越)

表 1 電車内等での携帯電話使用マナーの最近の主な動き (平成 27 年 12 月時点)

\begin{tabular}{|l|l|}
\hline 平成 26 年 7 月 & 関西（関西鉄道協会（私鉄 24 社), JR 西日本) \\
\hline 平成 27 年 10 月 & 関東, 東北, 甲信越（JR 東日本等の 37 社局） \\
\hline 平成 27 年 12 月 & $\begin{array}{l}\text { 東海（JR 東海, 名古屋市交通局, 名古屋鉄道) } \\
\text { 九州（JR 九州等の } 11 \text { 社局） }\end{array}$ \\
\hline
\end{tabular}

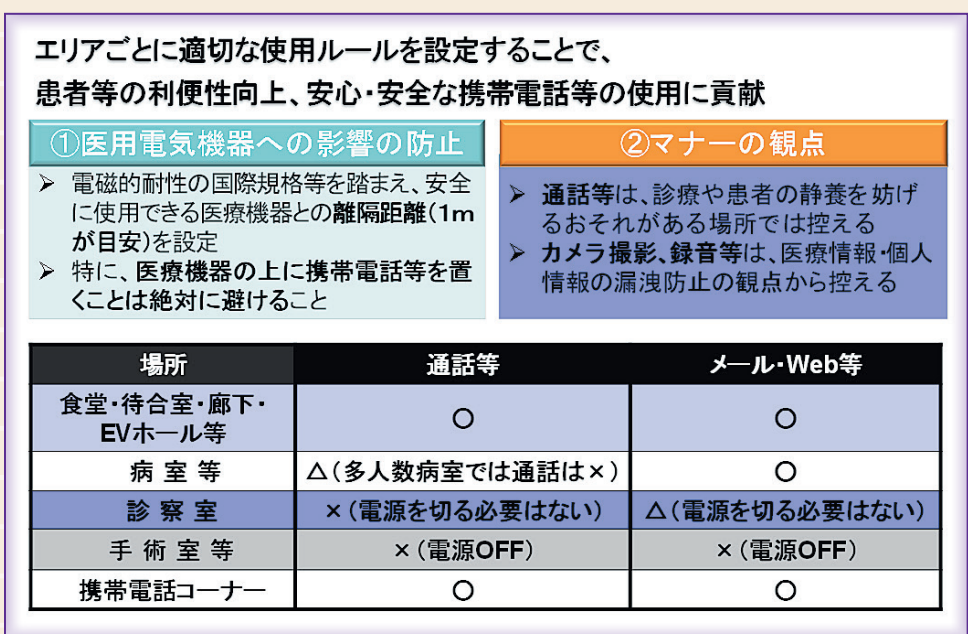

図 7 医療機関における携帯電話等の使用に関する指針 


\section{背景}

- 医療機関において電波を利用する機器の普及が拡大するとともに、患者等による医療機関での 無線機器の利用が増加している。

- 医療機関における電波管理等が適正になされていない場合には、医療機器にトラブルが発生したり、 高度な医療ICTシステムを導入する際の弊害となるだけでなく、事故等につながることが危惧される。 【医療機関で生じているトラブルのイメージ】

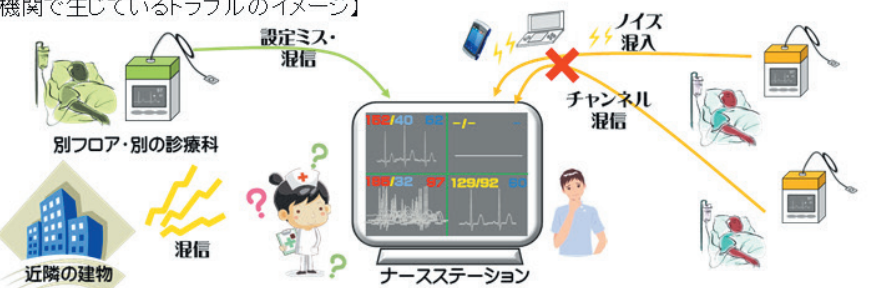

総務省・厚生労動省で連携し、医療機関!における電波利用推進部会」 (電波環境協議会に設置)において、2015年9月から検討を開始

2016年3月頃、報告書及び医療機関において 適正な電波利用を実現するための手引きを取りまとめ

\section{医療機関における適正な電波利用環境の実現}

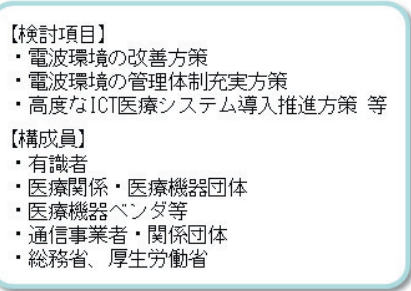
電波環境の改善方第 【構成員】 - 有識者 ·医療関係・医療機器吋体 通信事業者. 関儌団体 総務省、厚生労㗢省

図 8 医療機関における電波利用推進の検討

ぎ議論を深めることが必要である。

平成 28 年 3 月頃，同部会での検討結果を踏まえた, 医療機関で安心・安全に電波を利用するための手引きを 取りまとめ，公表等を行っていく計画である.

\section{4 今後の課題}

経済活動や日常生活の中で電波の重要性はますます 高まることが予測されることから，安心・安全な電波利 用環境を継続的に確保するための取組みを引き続き推進 していくことが求められている.

\section{（1）新たな無線利用機器への対応}

非常に高い周波数を用いたシステムや，ウェアラブル 機器等を用いた新たなサービスの実現が予想されるが, これらによる人体への影響等について早急に科学的な検 証を行い，その知見の指針への導入等が必要となる.

（2）電波の安全性に関するリテラシーの向上

総務省では，電波の安全性に関する認知度の向上を図 るリスクコミュニケーションの一環として，パンフレッ トの作成やホームページでの公開, 電話相談空口の設置, 説明会の開催などに取り組んでいる ${ }^{(7)}$. 最新の科学的知 見に基づいた電波の安全性に関する情報の周知に務めて いくことが必要である。
文献

（1）電波防護指針，http://www.tele.soumu.go.jp/j/sys/ ele/medical/protect/index.htm

(2) WHO の電磁波に関する EHC，http://www.who。 int/peh-emf/research/rf_ehc_page/en/

(3) ICNIRP が発行するガイドライン等の文書, http:// www.icnirp.org/en/publications/index.html

（4）「医用電気機器への電波の影響を防止するための携帯 電話端末等の使用に関する指針」(不要電波問題対策 協議会. 平成 9 年 4 月 ), http://www.emcc-info. net/others/keitai.html

（5）「各種電波利用機器の電波が植込み型医療機器等へ及 ぼす影響を防止するための指針」の改訂 (平成 27 年 8 月), http://www.soumu.go.jp/menu_news/s-news/ 01 kiban 16 02000106.html

（6）「医療機関における携帯電話等の使用に関する指針 等」(電波環境協議会。平成 26 年 8 月), http:// www.emcc-info.net/info/info2608.html

（7）電波利用ホームページ，http://www.tele.soumu.go. jp/j/sys/ele/index.htm

\section{篠澤康夫}

平 13 早大大学院理工学研究科了. 同 年総務省入省. 主に総務省において情 報通信分野行政に関する業務に従事. 現在, 総務省総合通信基盤局電波部電 波環境課課長補佐.

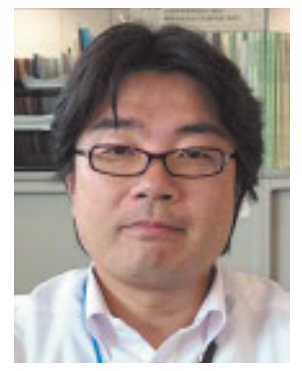

